\title{
The Power of Fertility and Its Importance for the Concept of Sustainable Development
}

\author{
Potęga płodności i jej znaczenie dla idei zrównoważonego rozwoju
}

\author{
Zuzanna Jakubowska ${ }^{1,2}$, Karolina Koza ${ }^{1,3,4}$, Wojciech Leder ${ }^{1,4}$, Aleksandra Owczarczyk ${ }^{1,4,5}$, \\ Zuzanna Skorupka ${ }^{1,3,5}$, Tomasz Wróblewski ${ }^{1,5}$ \\ ${ }^{1}$ College of Individual Inter-disciplinary Studies, University of Silesia in Katowice, Poland \\ ${ }^{2}$ Krzysztof Kieślowski Film School, University of Silesia in Katowice, Poland \\ ${ }^{3}$ Faculty of Theology, University of Silesia in Katowice, Poland \\ ${ }^{4}$ Faculty of Law and Administration, University of Silesia in Katowice, Poland \\ ${ }^{5}$ Faculty of Humanities, University of Silesia in Katowice, Poland \\ ORCID ZJ https://orcid.org/0000-0002-1727-8303; KK https://orcid.org/0000-0001-8416-2805; WL https://orcid.org/0000-0003-1921-7931; \\ A0 https://orcid.org/0000-0002-7091-6132; ZS https://orcid.org/0000-0002-1659-9439; TW https://orcid.org/0000-0001-6767-3320• \\ wojciech.leder@onet.pl \\ Received: 20 May, 2021; Revised: 26 July, 2021; Accepted: 10 Aug, 2021
}

\begin{abstract}
Demographic changes are one of the indicators of sustainable development, expressed by the value of the natural increase in the human population, resulting directly from the fertility level, which is the subject of this article. Human fertility is a complex potential conditioned by the environmental, social, and economic factors. The multi-dimensional relations of fertility that may affect its level, constitute an unlimited field of research, study, and analysis. The inter-disciplinary scope of fertility research conducted by the authors has shown that fertility is an issue that, in its historical, social, political, and medical aspects, has the potential of contributing to societal development and raising the standard of living. The aim of this article is to answer the question: whether and how the fertility of an individual has an impact on the idea of sustainable development. To achieve this, the available literature was analysed and synthesised, as well as supplemented with information provided by experts in the field. The article incorporates presentations of selected fertility determining factors, methods of measuring fertility potential, and diverse contexts, such as the impact of fertility on history and its relationship with the freedom of the human individual. Moreover, the authors present the relationship between the fertility of an individual, and the assumptions and postulates of the idea of sustainable development.
\end{abstract}

Keywords: power of fertility, fertility, sustainable development

Streszczenie: Jednym ze wskaźników zrównoważonego rozwoju są zmiany demograficzne wyrażane wartością przyrostu naturalnego populacji ludzkiej, którego stan wynika bezpośrednio z poziomu płodności (fertility) będącej przedmiotem rozważań niniejszego artykułu. Płodność człowieka jest złożonym potencjałem uwarunkowanym czynnikami środowiska przyrodniczego, społecznego i gospodarczego. Wielowymiarowe powiązania płodności, które mogą wpłynąć na jej stan, stanowią nieograniczone pole badań, studiów i analiz. Interdyscyplinarny zakres badań płodności, przeprowadzony przez autorów, pokazał, że płodność jest zagadnieniem, które zarówno w aspekcie historycznym, społecznym, politycznym i medycznym jest potencjałem przyczyniającym się do rozwoju społeczeństw i poziomu ich życia. Celem artykułu jest odpowiedź na pytanie: czy i w jaki sposób płodność jednostki ma znaczenie dla idei zrównoważonego rozwoju. By to osiągnąć, 
przeprowadzono analizę oraz syntezę dostępnego piśmiennictwa uzupełnioną o informacje przekazane przez ekspertów z przedmiotowego zakresu. W pracy zostały zaprezentowane: wybrane czynniki warunkujące płodność, sposoby mierzenia potencjału płodności oraz zróżnicowane konteksty, takie jak wpływ płodności na historię i jej powiązania z wolnością jednostki ludzkiej. Ponadto autorzy przedstawili powiązania między płodnością jednostki a założeniami oraz postulatami idei zrównoważonego rozwoju.

Słowa kluczowe: siła płodności, płodność, zrównoważony rozwój

\section{Introduction}

This article outlines a particularly important aspect of every human's life, which is the possibility to procreate, which can be interpreted from two perspectives: one as fertility, and the other as fecundity. The concept of fecundity in this article is understood as reproduction of the entire society. In order to study it, one should use demographic and administrative tools, such as statistical yearbooks or church records (especially useful when examining the past). On the other hand, there is fertility, defined as a factor of each individual's sexual health, the ability to produce offspring, which can be measured and assessed, thanks to medical tests performed on a specific person (Leridon 2007, 340-341). This understanding of fertility is the main issue of this article.

Fecundity as understood, according to the above definition, is a component of the idea of sustainable development, because it directly concerns the values represented by the postulates of the philosophy in question; however, it is also worth considering whether fertility belongs on the list of these postulates, as well. Therefore, in this article we will look at the multi-dimensional power of individual fertility, which every human being can utilise, reject, or protect. The aim of the article is to answer the question whether and how individual fertility fits in with the idea of sustainable development. The answer to this question has been presented in an inter-disciplinary perspective, with particular emphasis on the situation in central Europe. The methodological basis for this article was the analysis and synthesis of the available literature, electronic resources, and information provided by experts in the field. The researchers conducted queries of publications on fertility and sustainable development, interviewed an expert, then analysed and synthesised the obtained information.

\section{Fertility from an inter-disciplinary perspective}

In order to relate fertility to the idea of sustainable development, one must first understand what is the fertility of a human being. It is extremely difficult to frame the concept of fertility within one definition, because it is a multi-faceted potenti al within every human being. Therefore, in the article below, fertility and its importance is described in selected contexts, relevant to the presentation of the subject at hand. Various aspects of fertility will be presented in the following manner:

1. History: how fertility influenced the histories of nations and politics;

2. Fertility determining factors;

3. Measures of fertility;

4. Freedom of the individual; a person, having become acquainted with the above aspects, can make an independent decision about actions regarding fertility.

\subsection{Fertility and history}

John J. Mearsheimer in his work, titled: "The Tragedy of Great Power Politics" notes the importance of population factors in politics. The researcher points to two aspects, through which, he shows the impact of the population on shaping the power of the state. These are economic and military factors (Mearsheimer 2019, 76). The military factor is simply army 
size, but it is the second factor that seems to be more important from the point of sustainable development research. The author draws attention to the concept of latent power (Mearsheimer 2019, 54), and attempts to measure this aspect on the basis of demographic and economic data (Mearsheimer 2019, 83-85). Thus, the researcher shows just how strong is the relationship between demography and the economic development of a nation. He demonstrates that countries with large populations can aspire to the role of a superpower. The population potential is not always harnessed. Comparing the United States and the Soviet Union to India and China during the Cold War, shows that. Mearsheimer sums up his deliberations with this phrase: "A large population does not guarantee great wealth, but great wealth requires a large population." (Mearsheimer 2019, 77)

Demographic issues determined the fate of nations, as exampled by the situation that affected the Polish-Lithuanian Commonwealth in modern times. As Tadeusz Srogosz, a history of medicine researcher, notes: "Many eighteenth-century journalists, considering de-population as the source of Poland's weakness, raised, among other things, the problem of improving well-being as a quantitative and qualitative factor in increasing population potential. As a result of medical research development and the improvement of sexual awareness, the phenomenon of fertility is sporadically the subject of scientific research." (Srogosz 1995, 23-30) The Polish-Lithuanian Commonwealth was destroyed by a number of military conflicts, and the reduced population potential could have contributed to its collapse and the partitions of the state.

Fertility was enormously important throughout history, and that is very clear when we trace the political history of the world. In the Middle Ages, in patrimonial states, the monarch was the ruler, but also the owner of the land (Manteuffel 1964, 632). This is why Medieval rulers traditionally divided the country between the heirs in the event of the death of their father. As a result, the state was split into smaller principalities. Polish history is no exception. Bolesław III Wrymouth wanted to prevent a territorial breakdown by partitioning the state into districts and bestowing them upon his five sons. Before his death, he therefore, tried to introduce legislation that would prevent the breakdown of the state (Wyrozumski 1999, 136). The ruler, himself, had previously come into conflict with his father and brother over influence in the country, and saw similar situations in Hungary and Russia. However, these political safeguards implemented by the dying monarch, turned out to be insufficient, and many historians consider this date to be the beginning of the political disintegration of the Polish Kingdom (Wyrozumski 1999, 137).

The district breakdown of the Kingdom of Poland in 1138, is just one of many events, in which the issue of fertility is related to the political history of a country. Other examples of such events, include civil wars that broke out, whenever there was no heir or when the paternity of the deceased ruler was questioned. These enormous conflicts were especially pronounced in the ancient world. After the sudden death of young Alexander the Great, it was impossible to save the integrity of the state. His advisers fought for many years, for influence, in the so-called Wars of the Diadochi. Similarly, in the Roman Empire, when the Antonine dynasty ended with the slaying of Commodus, which resulted in the civil war of 193-197 A.D. After the murder of Severus Alexander, the state was further de-stabilised during the so-called "Crisis of the Third Century" (235-284). All these conflicts resulted in de-stabilisation and escalating anarchy, as well as the economic collapse of the state. At one point in modern history, the Hapsburg dynasty achieved significant political dominance. Their motto was: "Let others wage war. You, happy Austria, marry!" The motto emphasises how this dynasty benefitted greatly, and expanded its influence by way of royal marriages, and not through wars. 


\subsection{Determinants of fertility}

Fertility disorders may affect both men and women (Mianowska et al. 2015, 49-56). Amongst men, we can distinguish three sperm-related problems: low sperm count, poor motility, swimming problems, and poor morphology (improper shape).

Poor sperm health is caused by smoking, cycling, or using a sauna and jacuzzi, which may lead to a temporary reduction in sperm count (Raupp 2016, 45-46). Wearing tight underwear, as well as taking hot baths on a regular basis, may increase the temperature of the testicles (Kaye 2009, 84). Obesity may inhibit testosterone production (Bojanowska and Kostecka 2018, 431). Both physical and mental stress can lead to a temporary reduction in sperm count. Medical conditions such as diabetes, thyroid disease, Cushing syndrome, heart attack, liver or kidney failure, as well as the prescribed medications used to treat these conditions, may affect sperm quality. Toxic pesticides and chemicals in the environment that disrupt the hormonal balance, may negatively affect the functioning of the testicles or the endocrine system, thus resulting in a reduced sperm count (Raupp 2016, 46). Other chemical factors impairing male fertility also include lead, carbaryl, carbon disulfide, marijuana, and cocaine (Miranowicz-Dzierżawska 2012, 12). Regular use of cocaine for a period of five years or more, causes adverse changes in semen parameters, such as reduced sperm count or changes in sperm morphology (Pasterniak-Winiarski 2019, 239-247). Abuse of addictive substances, such as cocaine, marijuana, as well as excessive amounts of alcohol and anabolic steroids, can temporarily reduce the count, quality, and motility of sperm (Raupp 2016, 45-46). Nanoparticles found in products such as drugs, clothing, and cosmetics, may also be harmful to fertility. A correlation has been proven between exposure to air pollution and steroidogenesis and spermatogenesis disorders (Pasterniak-Winiarski 2019, 239-247).
Environmental hazards to female fertility, primarily include: eating food contaminated with pesticides, drinking water from plastic bottles, toxins in the air entering the body, fatigue, and stress affecting our health, and thus, fertility (Raupp 2016, 110). There is a link between stress hormones and hormones responsible for the proper functioning of sexual organs (Dembińska 2008, 35). Emotional stress can be the cause of anovulation. Many women report irregular periods in times of increased stress (Kaye 2009, 63). The intensity of stress and its duration lead to an imbalance of the endocrine system, and thus to reproductive health disorders (Chazan 2004, 20-24). People more resistant to stress are people who lead a healthy lifestyle, which consists of: a diet rich in nutrients, adequate sleep, and stable family and work environments. It has been proven that a high cholesterol and high fat diet causes ovulation disorders in women (Bojanowska and Kostecka 2018, 427). Chemical compounds such as pesticides, plastics, or phyto-estrogens (e.g., found in soybeans, added to numerous food products) have a destructive effect on female hormones, as well as reproduction, and are associated with an increase in reproductive health problems, as well as reduced fertility (Raupp 2016, 4546). Pesticides are a diverse and numerous group of chemical compounds of both natural and synthetic origin, commonly used to protect arable crops (Golec, Hanke, and Dąbrowski 2003, 465). Exposure to pesticides and environmental toxins affects fertility, so it is important that products meant for consumption are pesticide-free and non-genetically modified (Raupp 2016, 94). Toxic substances found in cosmetics and cleaning products affect human hormones and, as a result, alter fertility (Raupp 2016, 110-111). Use of nicotine weakens the female reproductive potential, as well, and doubles the probability of infertility (Bojanowska and Kostecka 2018, 434). 


\subsection{Measures of fertility}

A large section of the population is most probably still unaware of how their own fertility can be measured, which is why there is an urgent need to spread this particular information. Sometimes people start to actively seek knowledge, only in the event of having problems with conception, not realising that the sooner they start the treatment, the better. Age has a huge impact on fertility in both men and women.

In women, it is associated with a declining number of follicles. A definite number of them is available in a lifetime, known as the ovarian reserve. The ovarian reserve test determines the female reproductive potential, by measuring the levels of Anti-Mullerian Hormone (AMH) in the blood, which indicates the number of eggs available at the time of the test and reveals how healthy they are. A woman who knows her AMH levels, and is confident her body is functioning properly, can start trying for a baby. If her health condition does not allow it because, for example, she is suffering from cancer or premature ovarian failure (POF), or is already in her 4os, she can decide to cryopreserve her oocytes and embryos, by means of vitrification (Krawczyńska and Słowińska-Srzednicka 2016, 925). The age of the man is an important factor when deciding on invitro fertilisation. French studies in 1995, showed that for men over 35 years of age, the probability of getting pregnant using the IVF method decreased by $52 \%$, compared to those under 25 years of age (Mathieu 1995, 1090-1097). Pregnancies in women, older than 35 , were defined as geriatric.

It is worth paying attention to any deviations from the norm during menstrual cycles. The gynaecologist may perform an ultrasound scan, during which the endometrium and ovarian structures are assessed as well as the number of antral follicles. This assessment can also be made using other diagnostic and surgical methods, e.g., hysterosalpingography, laparoscopy, hysteroscopy. Hormone diagnostics should be performed regularly (examining, among others, the levels of: $\mathrm{FSH}, \mathrm{LH}$, and prolactin).

It is also worth performing diagnostic tests to rule out the following diseases as soon as possible: hypothyroidism, Addison's disease, diabetes, myasthenia, Crohn's disease, vitiligo, pernicious anemia, systemic lupus and rheumatoid arthritis. People who suffer from these ailments have an increased likelihood of being affected by POF (Warenik-Szymankiewicz 2005, 360).

Until recently, it was believed that male fertility was not affected by age. Unfortunately, the few but high-profile examples of geriatric fathers, propel this false myth, and it is still falsely regarded as common knowledge. The risk of hormonal, anatomical, and morphological changes increases with age. All of this can lead to hypogonadism, sometimes comparable to menopause (Harris et al. 2011, 184-190). It is worth examining semen quality, every few years. In fact, statistical studies show that, in order to precisely determine the average starting point of semen quality, as many as 14 measurements must be made (Castilla et al. 2006, 2082-2088), because the quality of semen can vary significantly, depending on the day and current factors (such as body temperature, for example). However, the general assumption is that it is enough for the sperm analysis to be conducted three times to obtain relatively precise results.

A sperm quality test assesses the concentration, viability, motility, and morphological structure of sperm, as well as the quality of seminal fluid. According to official WHO guidelines, it is recommended conducting the semen analysis, after a period of sexual restraint (time since the last semen ejaculation) of two to seven days (WHO 2020). The macroscopic evaluation of semen is ready after just thirty minutes (no more than sixty), from the collection of the semen sample. During this examination, macroscopic features are assessed: volume, viscosity, $\mathrm{pH}$, colour, odour, and microscopic parameters: number, viability, motility, and structure (morphology) of sperm. The sperm analysis 
can be broadened by examining the organisation of the genetic material of sperm, their maturity, and the presence of sperm antibodies.

Other important tests to be aware of: blood testosterone, $\mathrm{LSH}, \mathrm{LH}$, and prolactin tests, and an ultrasound of the testicles, to check the patency of the sperm discharge ducts.

Material is collected from the semen for the examination of sperm chromatin, i.e., the ability of sperm to transfer genetic material. This test must be performed from a new sperm sample. Sperm chromatin is affected by many lifestyle factors (e.g., cigarette smoking or air pollution).

Other tests to help assess male fertility, include: the MAR test, semen culture and antibiogram, nuclear protein assessment, redox test, semen plasma total antioxidant capacity evaluation, redox balance test, sperm survival test, biochemical analysis of semen plasma, and the acrosin test.

Both infertility and an excessive birth rate are serious societal challenges. The pace of social development depends on them. Demography is the study of such phenomena.

\subsection{Fertility as freedom}

Fertility could be compared to the concept of freedom for two reasons. First, fertility is an element of personal health, and therefore, is protected under human rights and freedoms. Second, fertility is, by nature, a potential that can be used according to free will, which, in the broad sense, makes it "freedom". This duality of the concept of fertility is parallel to the similarly divided concept of freedom (a value both social and individual). Sustainable development also refers to activities on two scales: macro (global, social) and micro (from the perspective of each individual).

The World Health Organisation defines health as "a state of complete physical, mental, and social well-being, and not merely the absence of disease or infirmity." (Constitution 1946, Preamble, 2nd sentence). Historically, the Ancient Greeks used the concept of isonomia, or harmony, to describe an equilibrium both in the body and the state. The Greek concept of isonomia can be translated as "equal allocation" or "equality before the law" (Mączak 1986, 57). Thus, this ancient concept is not far removed from the modern idea of sustainable development, which includes the equal protection of the right to health. This human right is enshrined in Article 68 of the Polish Constitution ("Everyone shall have the right to have his health protected"). Article 12 of the International Covenant on Economic, Social, and Cultural Rights mentions the right to "the enjoyment of the highest attainable standard of physical and mental health." The Universal Declaration of Human Rights mentions this protection indirectly in Article 3 ("Everyone has the right to life, liberty, and security of person"), and in Article 25 ("Everyone has the right to a standard of living adequate for the health and well-being of himself, and of his family").

Fertility, understood as freedom, is also realised in other human rights, this time the socalled "Reproductive rights". The Universal Declaration of Sexual Rights defines the "right to make free and responsible reproductive choices." (Declaration 1999, paragraph 8)

This right, and the aforementioned right to health, are in line with the goals of the UNGA Resolution defining sustainable development. These goals are: "Reproductive health", by ensuring universal access to "sexual and reproductive health-care services, including for: family planning, information, and education" (Agenda 2015, goal 3.7), and the goal of ensuring access to "sexual and reproductive health and reproductive rights." (Goal 5.6)

The duality of the concept of fertility overlaps with the concept of freedom, which is both an individual and a social value. This division is reflected, for example, in two distinct concepts of freedom created by John Stuart Mill and Montesquieu. The first one identifies freedom as the basis for the existence of societies (Rab 2016, 197). The second is concerned with the individual, and his or her "inner sphere of consciousness" 
(Mill 2005, 129-133). Mill's concept relates to the micro scale - the potential of a single human being. Montesquieu's view, in turn, reflects contemporary thinking about health and fertility as common goods, important for sustainable development on a global scale. Both concepts are the root of sustainable development. The freedom of self-determining individuals is the starting point for co-operation for the common good.

For Montesquieu, liberty is a social value, the basis of morality, because "it can consist only in the power of doing what we ought to will, and in not being constrained to do what we ought not." (Nazar-Gutowska 2012, 131) The philosopher claimed that "the liberty of every citizen constitutes a part of the public liberty", so that liberty makes sense only for the society it serves (Monteskiusz 2016, nb. 1218). The same is true of fertility. It is supported by various social programmes and protected under the universal right to healthcare. If we were to approximate Montesquieu's concept a little more, it can be said that fertility is the freedom to do what nature and society demand of human beings. This is one aspect of fertility. The second, understood in the spirit of Mill's liberalism, is that fertility means the freedom to choose what each person can do with it. This understanding of fertility can be found in the aforementioned paragraph 8 of the Universal Declaration of Sexual Rights.

Fertility is a potential that can be exercised in accordance with free will. Therefore, it can be referred to as a "freedom". Although it is not a freedom in the strict sense of the law, it is nevertheless a value that is protected by human rights. These rights are: the right to health and the so-called "reproductive rights", the protection of which, is provided by declarations on sustainable development.

Fertility is sustainable development on a micro scale of the development and future of every single individual, then, a family, and then, the society. Isaiah Berlin referred to freedom as an "open door", where "freedom is a matter of the doors open to me, not of whether I happen to choose to go through them." (Jahanbegloo 1991, 182) Disregarding our health and fertility, we restrict our development, we close the door marked "fertility". According to Berlin, "freedom is an inalienable, inherent feature of every choice (...), in human activity." (Rąb 2016, 180) It is, therefore, a pre-requisite for sustainable development.

\section{Fertility and the idea of sustainable development}

The inter-disciplinary character of fertility presented in the above chapter will be compared in the following section, with the assumptions and postulates of the sustainable development philosophy, thus, demonstrating the connections between these areas. These connections will be fleshed out on many levels, both in terms of general features and specific aspects.

At the very start of our deliberations, it is worth mentioning that both the philosophy of sustainable development and fertility are multi-faceted issues. They touch upon various plains of human activity and world functionality. It is impossible to talk about changes in global perspectives, without paying attention to the individual. It is impossible to care for global sustainable development, whilst neglecting the health and education of every human being.

The vision of sustainable development refers to the most important global challenges, such as: human rights, combating poverty, gender equality, security, health, universal education, and intercultural dialogue. Two of these goals are especially important: access to health care and universal education. There is a link between the concept fertility and these two sustainable development challenges. The right to healthcare, as a human right, belongs to the axiological background of the idea of sustainable development.

The same problems we refer to, in the study of the idea of sustainable development, we also encounter in the study of human history. Throughout history, demographic issues are noticeable, which have had a direct impact on the fate, or even the existence of societies or empires. On 
the other hand, in the theory of sustainable development, the growing world population has always been an important issue. As far back as 1987, in a UN document titled: "Our Common Future: Report of the World Commission on Environment and Development" (WCED 1987, 18), in a chapter on guidelines for sustainable development policy, the issues of Population and $\mathrm{Hu}$ man Resources were mentioned first and foremost. The document underscores that "the world has real choices. Policies to bring down fertility rates, could make a difference of billions to the global population, next century. (...) Giving people the means to choose the size of their families is not just a method of keeping population in balance with resources; it is a way of assuring - especially for women, the basic human right of self-determination."

Additionally, caring for future generations is the foundation of the idea of sustainable development. Thus, the issue of fertility is an important aspect of the idea of sustainable development. UNESCO defines sustainable development as "development that meets the needs of the present, without compromising the ability of future generations to meet their own needs." (WCED 1987) This definition indicates the necessity to keep in mind the needs of future generations, and to consider the future consequences of present-day decisions. Caring for the broader, multi-faceted issue of fertility has an impact on human life today, in the immediate future, and for future generations.

Having children and satisfying the need for motherhood, also play an important role in family life (Krupa and Szmidt 2019, 15). The assumptions of sustainable development aim at eliminating factors that harm human health, including those that cause fertility disorders (Szymborski 2012, 4). Environmental factors influence our epigenetic states, which may hinder the ability of couples to become pregnant (Raupp 2016, 4546). Factors causing infertility are present in both the natural environment and the environment understood as personal lifestyle. In order to ensure the biological survival of citizens, the state policy should strive to create social and economic conditions beneficial for the ongoing, demographic processes (Szymborski 2012, 4).

The fertility level depends, not only on individual free will and overall health, but also on complex, environmental factors. From the point of view of biology, a person's usefulness is the result of his or her ability to procreate and produce offspring. Only a healthy person, who maintains a high fertility potential, can fulfil subsequent demands imposed by society, and take part in the process of realising sustainable development goals. Fertility is environmentally conditioned by factors related to lifestyle, place of residence, and diet. The perspective of sustainable development should encourage the reconciliation of economic development with human health and fertility. Factors such as air pollution, the presence of heavy metals, pesticides, and nanoparticles in the environment are the result of industrialisation, and, as a result, have a negative impact on human fertility.

Health and liberty are two of the most important values in human life. Both are fundamental in the axiology of the concept of sustainable development. The content of the 2030 Agenda for Sustainable Development urges their equal protection. The topic of fertility relates not only to health, but also to freedom. Fertility is parallel to freedom because it constitutes potential for the future. When we disregard health, we neglect fertility and, as a result, we deprive ourselves of the freedom it offers.

Fertility is often only taken care of when it is reduced or absent. Infertility affects $10-16 \%$ of the population aged 15-49. In the scale of the Polish population, this amounts to over a million infertile couples. Understanding how to take care of your health, mental condition and how to avoid the risk factors, can prevent infertility, as well as its further consequences, such as therapies and expensive treatments. In the future, this health awareness should 
help reduce the constantly increasing percentage of infertile couples. Every person caring for fertility, thus cares about his or her health, and this is fundamental, not only for the lives of individuals, but also for the sustainable development of the entire global population. Although the state affects the factors determining fertility levels through economic regulations, in the end it is up to each individual's decision, whether he or she will maintain full fertility.

In summary, we can assert that fertility is of fundamental importance for every person and society as a whole, as it is an important element of sustainable development. The concept of sustainable development includes a balance of such areas of human life, as the environment, economy, and society. In essence, it means taking care of future generations, while referring to actions on a macro (global, social) and micro scale (from the perspective of every individual). Human activity should be guided by prudence in both these approaches - individual and collective (Jaron 2014, 126). Sustainable development begins with the individual and his or her prudence, i.e., preserving the fertility potential.

\section{Conclusion}

In the introduction to this paper, a question was posed: does an individual's fertility fit in with the idea of sustainable development? After conducting a multi-faceted, detailed analysis, the question must be answered in the affirmative. That is because both fertility in the general, demographic perspective (fecundity), and also individual fertility, are closely related to the idea of sustainable development, where the needs of the current generation can be fulfilled, without diminishing the chances of future generations being able to fulfil those needs as well. It is worth emphasising that the above considerations apply to the entire human population, despite the fact that some of the analyses were based on data from central Europe.

Analysing fertility from the perspective of its importance in the history of nations has shown that states often ceased to exist due to a lack of successors to the throne. This often led to civil wars, and in medieval Europe, when the ruler had many descendants, the country was divided into districts. In order to counteract political fragmentation of the state, institutions were created to guarantee security, especially in times of de-population caused by war losses. Therefore, citizens' procreation, guarantees the security of the country, its development, and economic stability.

Another element connecting fertility with sustainable development, is the awareness of factors that impact upon fertility. Learning about how they are determined and how they influence the preservation of reproductive potential, contributes to how they are considered in the process of choosing a lifestyle and a place to live. The most important factors are connected to environmental conditions, such as water and air pollution, and available food quality.

All these issues correlate with the concept of freedom. On the one hand, fertility is considered a matter of individual freedom of every human being, understood as self-determination. On the other hand, the development of the global population depends on the level of the fertility of each individual. Thus, fertility correlates to the idea of sustainable development, which is a phenomenon implemented on two scales - local and global. The research results lead to the conclusion that neglecting personal health, in terms of fertility, leads to a permanent loss of the capacity for personal and social development, and at the same time, constitutes a self-limitation of an individual's freedom to decide about their own reproductive potential.

Fertility is one of the most important elements of human life, determining its future, as well as the sustainable development of future generations. The topics presented are extensive, inter-disciplinary, and inadequately researched. There is a necessity for more detailed, inter-disciplinary studies, taking into account, the connection 
between fertility and sustainable development in the context of environmental and social changes, as well as various other aspects. This is necessary to fully implement the very idea of sustainable development, because, as the ideas presented here show, the fertility of an individual, and the circumstances surrounding it, constitute an integral part of this idea.

Author Contributions: Conceptualization, Z.J., K.K., W.L., A.O., Z.S. and T.W.; Methodology, Z.J., K.K., W.L., A.O., Z.S. and T.W.; Investigation, Z.J., K.K., W.L., A.O., Z.S. and T.W.; Writing - Original Draft Preparation, Z.J., K.K., W.L., A.O., Z.S. and T.W.; Writing - Review \& Editing, Z.J., K.K., W.L., A.O., Z.S. and T.W.; Supervision, K.K. All authors have read and agreed to the published version of the manuscript.

Funding: This research was funded by the College of Individual Inter-disciplinary Studies at the University of Silesia in Katowice, in 2020.

Institutional Review Board Statement: Not applicable.

Conflicts of Interest: The authors declare no conflict of interest. The founding sponsor had no role in the design of the study; in the collection, analyses, or interpretation of data; in the writing of the manuscript, and in the decision to publish the results.

Acknowledgments: The authors would like to thank Assoc. Prof. Edyta Sierka, Director of the College of Inter-disciplinary Individual Studies at the University of Silesia in Katowice, for her substantive support and remarkable intellectual contribution to our research.

\section{References}

Agenda 2015 - The 2030 Agenda for Sustainable Development, UN General Assembly Resolution, signed 25 September 2015 (A/RES/70/).

Berlin, Isaiah. 1991. Dwie koncepcje wolności i inne eseje. [Two Concepts of Freedom and Other Essays]. Warszawa: Res Publica.

Bojanowska, Monika, and Małgorzata Kostecka. 2018. „Dieta i styl życia jako czynniki wpływające na płodność." [Diet and Lifestyle as Factors Influencing Fertility]. Kosmos 67(2): 425-439.

Castilla Josea A., Carlos Alvarez, Juan Aguilar, Cristina Gonzalez-Varea, and María Carmen Gonzalvo. 2006. "Influence of analytical and biological variation on the clinical interpretation of seminal parameters." Human Reproduction 18(10): 847-851.

Chazan, Bogdan. 2018. „Opieka prekoncepcyjna i wybrane problemy niepłodności małżeńskiej." [Preconceptual care and selected problems of marital infertility]. In Płodność i planowanie rodziny, [Fertility and family planning], edited by Zbigniew Szymański, 20-24. Szczecin: Wydawnictwo Pomorskiej Akademii Medycznej.

Constitution 1946 - Constitution of the World Health Organisation, signed on 22 July, 1946, in New York.

Declaration 1999 - The Universal Declaration of Sexual Rights, adopted by the General Assembly of the World Congress of Sexology on 26 August, 1999, in Hong Kong, and adopted by the WHO in 2002.

Dembińska, Aleksandra. 2018. Psychologiczne aspekty zmagania się kobiet $z$ nieptodnościa. [Psychological aspects of women's struggle with infertility]. Warszawa: Difin.

Golec, Joanna, Wojciech Hanke, and Sławomir Dąbrowski. 2003. „Ryzyko zaburzeń płodności u osób zawodowo eksponowanych na pestycydy." [The risk of impaired fertility in people professionally exposed to pesticides]. Medycyna pracy 54(5): 465-472.

Harris, Isaiah, Carolyne Fronczak, Lauren Roth, and Randall B. Meacham. 2011. "Fertility and the ageing male." Reviews in Urology 13(4), e184-e190.

Jahanbegloo, Ramin. 1991. Conversation with Isaiah Berlin. New York: Halban Publishers.

Jaroń, Magdalena M. 2014. „Podmiotowe podstawy zrównoważonego rozwoju." [Personalistic foundations of sustainable development]. In Zrównoważony rozwój. Debiut naukowy, [Sustainable development. Scientific debut], edited by Tomasz Jamczura, and Hanna Kretek, 126-133. Racibórz: Wydawnictwo PWZS w Raciborzu.

Kaye, Philippa. 2009. Ptodność, nieptodność, bezpłodność. [Fertility and infertility]. Warszawa: Wydawnictwo Lekarskie PZWL.

Krawczyńska, Monika, and Jadwiga SłowińskaSrzednicka. 2016. „Zastosowanie oznaczeń stężeń hormonu antymüllerowskiego (AMH) w diagnostyce chorób endokrynnych." [The utilization of anti-müllerian hormone 
$(\mathrm{AMH})$ plasma level measurements in diagnosis of endocrine diseases]. Postęp Nauk Medycznych 29: 921-928.

Krupa, Aleksandra, and Marta Schmidt. 2019. "Niepłodność kobieca w wyniku wybranych zaburzeń hormonalnych - przegląd literatury." [Female infertility as a result of selected hormonal disorders - literature review], In Wybrane zagadnienia z zakresu ginekologii, położnictwa $i$ seksuologii, [Selected issues in the field of gynecology, obstetrics and sexology], edited by Violetta Skrzypulec, 7-16. Katowice: Śląski Uniwersytet Medyczny.

Leridon, Henri. 2007. "Studies of fertility and fecundity: comparative approaches from demography and epidemiology." Comptes Rendus Biologies 330(4): 339-346.

Mączak, Antoni. 1986. Rzadzacy i rzadzeni: władza $i$ społeczeństwo w Europie wczesnonowożytnej. [The Ruling and The Ruled: Power and Society in Early Modern Europe]. Warszawa: Państwowy Instytut Wydawniczy.

Manteuffel, Tadeusz. 1964. „Feudalizm.” [Feudalism]. In Wielka Encyklopedia Powszechna, [Great Universal Encyclopedia]. vol. 3, edited by Bogdan Suchodolski, 632. Warszawa: PWN.

Mathieu Cyrille, René Ecochard, Victoria Bied, Jacqueline Lornage, and Jean-Claude Czyba. 1995. "Cumulative conception rate following intrauterine artificial insemination with husband's spermatozoa: influence of husband's age." Human Reproduction 10(5):1090-1097. https:// doi.org.10.1093/oxfordjournals.humrep.a136100.

Mearsheimer, John Joseph. 2019. Tragizm polityki mocarstw. Kraków: Universitas.

Mianowska, Klaudia, Magdalena Lewicka, Magdalena Sulima, Dorota Koczkodaj, and Artur Wdowiak. 2015. „Ocena kariotypu niepłodnych par." [Karyotype evaluation of infertile couples]. European Journal of Medical Technologies 3(8): 49-56.

Mill, John Stuart. 2005. O wolności. Warszawa: PWN. Miranowicz-Dzierżawska, Katarzyna. 2012. „Substancje działające szkodliwie na rozrodczość zagrożenia, narażenie, uregulowania prawne." [Substances toxic for reproduction - threats, exposure, legal regulations]. Bezpieczeństwo Pracy: nauka i praktyka 12: 11-15.
Monteskiusz, Charles. 2016. O duchu praw. [The spirit of the laws]. Kraków: Vis-à-vis Etiuda.

Nazar-Gutowska, Katarzyna. 2012. Groźba bezprawna w polskim prawie karnym. [An unlawful threat in Polish criminal law]. Warszawa: Wolters Kluwer.

Pasterniak-Winiarski, Anna. 2019. „Wybrane czynniki środowiskowe, a ryzyko niepłodności mężczyzn." [Selected Environmental Factors as a Risk of Male Infertility]. Kosmos 68(2): 239-247.

Rąb, Łukasz. 2016. „Problem wolności a idea zrównoważonego rozwoju." [The Problem of Freedom and The Idea of Sustainable Development]. Transformacje 1-2 (88-89): 172-186.

Raupp, Aimee E., and Marta Florea. 2016. Ty tez będziesz $w$ ciaży. [Yes, you can get pregnant]. Warszawa: Wydawnictwo Lekarskie PZWL.

Srogosz, Tadeusz. 1995. „Stan i potrzeby badań nad dziejami osiemnastowiecznej medycyny polskiej." [The Condition and the Needs of Research into the History of $18^{\text {th }}$-c. Polish Medicine]. Medycyna Nowożytna: studia nad historia medycyny 2: 23-30. Szymborski, Janusz. 2012. Zdrowie publiczne $i$ polityka ludnościowa. Rzadowa Rada Ludnościowa. [Public health and population policy. Government Population Council]. Warszawa: Zakład Wydawnictw Statystycznych.

Warenik-Szymankiewicz, Alina, and Radosław Słopień. 2005. „Genetyczne podłoże przedwczesnego wygasania czynności jajników." [Genetic aspects of premature ovarian failure]. Endokrynologia Polska 56(3): 359-358.

WCED (World Commission on Environment and Development). 1987. Our Common Future: Report of the World Commission on the Environment and Development. Oxford: Oxford University Press. WHO (World Health Organization). 2020. WHO laboratory manual for the Examination and processing of human semen. Accessed October 30, 2020. https://www.who.int/docs/default-source/ reproductive-health/srhr-documents/infertility/ examination-and-processing-of-human-semen5ed-eng.pdf?sfvrsn=5227886e_2.

Wyrozumski, Jerzy. 1999. Wielka Historia Polski. Tom 2: Dzieje Polski Piastowskiej (VIII w. -1370). [The Great History of Poland. vol. 2: The History of Piast Poland ( $8^{\text {th }}$ century-1370)]. Kraków: Bertelsmann Media. 